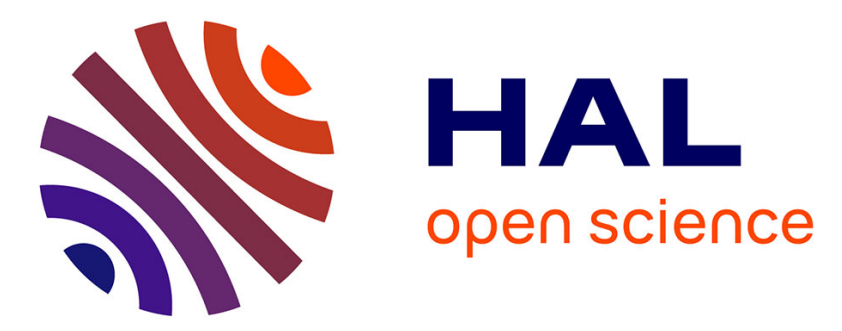

\title{
Designing management options to reduce surface runoff sediment yield with farmers: An experiment in south-western France
}

\author{
A. Furlan, J.C. Poussin, J.C. Mailhol, Yves Le Bissonnais, Silvio José Gumière
}

\section{- To cite this version:}

A. Furlan, J.C. Poussin, J.C. Mailhol, Yves Le Bissonnais, Silvio José Gumière. Designing management options to reduce surface runoff sediment yield with farmers: An experiment in south-western France. Journal of Environmental Management, 2011, 96 (96), pp.74 - 85. 10.1016/j.jenvman.2011.11.001 . hal-00662428

\section{HAL Id: hal-00662428 \\ https://hal.science/hal-00662428}

Submitted on 24 Jan 2012

HAL is a multi-disciplinary open access archive for the deposit and dissemination of scientific research documents, whether they are published or not. The documents may come from teaching and research institutions in France or abroad, or from public or private research centers.
L'archive ouverte pluridisciplinaire HAL, est destinée au dépôt et à la diffusion de documents scientifiques de niveau recherche, publiés ou non, émanant des établissements d'enseignement et de recherche français ou étrangers, des laboratoires publics ou privés. 
Author- produced version ot the article published in Journal of Environmental Management, 2011, 96,76-85.

The original publication is available at http://www.sciencedirect.com doi : 10.1016/j.jenvman.2011.11.001

1 DESIGNING MANAGEMENT OPTIONS TO REDUCE SURFACE RUNOFF AND 2 SEDIMENT YIELD WITH FARMERS: AN EXPERIMENT IN SOUTH-WESTERN 3 FRANCE.

4

Adriana FURLAN ${ }^{1}$, Jean-Christophe POUSSIN ${ }^{1}$, Jean-Claude MAILHOL ${ }^{2}$, Yves LE BISSONNAIS ${ }^{3}$, Silvio J. GUMIERE ${ }^{4}$

${ }^{1}$ IRD, UMR G-eau, Montpellier, France

${ }^{2}$ Cemagref, UMR G-eau, Montpellier, France

${ }^{3}$ UMR LISAH, Montpellier, France

${ }^{4}$ Laval University, Québec, Canada

\section{ABSTRACT}

To preserve the quality of surface water, official French regulations require farmers to keep a minimum acreage of grassland, especially bordering rivers. These agro-environmental measures do not account for the circulation of water within the catchment. This paper examines whether it is possible to design with the farmers agri-environmental measures at field and catchment scale to prevent soil erosion and surface water pollution. To support this participatory approach, the hydrology and erosion model STREAM was used for assessing the impact of a spring stormy event on surface runoff and sediment yield with various management scenarios.

The study was carried out in collaboration with an agricultural committee in an area of southwestern France where erosive runoff has a major impact on the quality of surface water. Two sites (A and B) were chosen with farmers to discuss ways of reducing total surface runoff and sediment yield at each site. The STREAM model was used to assess surface runoff and sediment yield under current cropping pattern at each site and to evaluate management scenarios including grass strips implementation or changes in cropping patterns within the catchment. The results of STREAM simulations were analysed jointly by farmers and researchers. Morever, the farmers discussed each scenario in terms of its technical and economical feasibility.

1 STREAM simulations showed that a $40 \mathrm{~mm}$ spring rainfall with current cropping patterns led 2 to $3116 \mathrm{~m}^{3}$ total water runoff and 335 metric tons of sediment yield at site A, and $3249 \mathrm{~m} 3$ 3 and 241 metric tons at site B. Grass strips implementation could reduce runoff for about $40 \%$ 34 and sediment yield for about $50 \%$ at site A. At site B, grass strips could reduce runoff and 
sediment yield for more than $50 \%$, but changes in cropping pattern could reduce it almost totally.

The simulations led to three main results: (i) grass strips along rivers and ditches prevented soil sediments from entering the surface water but did not reduce soil losses, (ii) crop redistribution within the catchment was as efficient as planting grass strips, and (iii) efficient management of erosive runoff required coordination between all the farmers using the same watershed. This study shown that STREAM model was a useful support for farmers' discussions about how to manage runoff and sediment yield in their fields.

Keywords: erosion; runoff; agriculture; land management options; participatory approach; modelling.

\section{INTRODUCTION}

Conflicts between agricultural production and environmental quality have grown steadily in recent decades due to the negative impacts of agriculture on the environment and particularly on water quality. Currently there is concern about the sustainability of conventional land-use practices on arable land throughout the world (Stoate et al., 2009). From the 1960s on, policies in most European countries aimed at developing intensive agriculture. Increasing yields required mechanisation and the use of fertilizers and pesticides. At the same time, reducing costs was encouraged by the creation of big farms and land consolidation (Robert, 2000). As a result, environmental problems such as runoff, erosion and water pollutions began to occur (Nearing et al., 2005; Toy et al., 2005). The consequences are of concern to the local authorities which have to face property damages induced by soil-laden water, road clearance and watercourse pollution both by sediments and agricultural chemicals (Papy and Douyer, 1991; Boardman et al., 1994).

Over the past 20 years, monitoring of surface water and groundwater in Europe revealed significant nitrate and pesticide contamination, mainly in France, where samples of surface water often exceeded the drinking water limits of $0.1 \mu \mathrm{g}$ pesticides per litre (Water Framework Directive, European Community decree 2000/60/EC). For example, the Comité de Bassin Adour-Garonne (2004) pointed out that 96\% of surface water in the Department Tarn and Garonne (south-western France) was contaminated by nitrates, phosphorus and pesticides, partially because erosive runoff in cultivated fields. Moreover, Probst (1985) 
Author- produced version ot the article published in Journal of Environmental Management, 2011, 96,76-85. The original publication is available at http://www.sciencedirect.com doi : 10.1016/j.jenvman.2011.11.001

reported total phosphorus concentration at $0.5 \mathrm{mg} . \mathrm{L}^{-1}$ in surface waters, and nitrate concentration from 60 to $130 \mathrm{mg} . \mathrm{L}^{-1}$ in subsurface waters according to the season.

In 2000, the European Community (EC) introduced the Water Framework Directive (WFD) as a way of restoring and preserving the quality of all water resources. The WFD, which is based on catchment areas, set targets of water quality to be achieved by 2015. Member States must implement management plans for every river basin to restore and to preserve the quality of surface, coastal and ground waters, and to ensure the protection of existing water stocks. In addition, Member States have to encourage all the stakeholders (e.g. local and regional authorities, farmers, water users and environmental organisations) to draw up, discuss and update their management plans (WFD, EC decree 2000/60/EC).

Since 1992, the Common Agricultural Policy (CAP) introduced instruments that are relevant to achieving better water management: set-aside land (lying fallow a part of arable land) to mitigate agricultural over-production, and agri-environmental measures (AEM) to control agricultural impacts on soil, water, air, biodiversity, habitats and land-use patterns. AEM implementation by farmers is initially only based on voluntary service and EC financial aid. In 1999, the new EC Rural Development Regulation reinforced environmental considerations with expansion of AEM. The CAP reform of 2003 introduced the cross-compliance principle that linked the full payment of CAP aids to farms and compliance with agri-environmental standards called "good agricultural and environmental condition" (GAEC). GAEC obligations constitute AEM baseline; they include in particular a part of the annual cropped area with permanent plant cover (PPC) to prevent soil erosion, and buffer strips (non-cultivated or grass planted) along water courses to prevent surface water pollution.

The first way to prevent water pollution by agricultural practices is to reduce the source of pollution, by choosing the right pesticide type, reducing application rates and improving spraying efficiency. The second way is to reduce the transport of pollutants in runoff, in solution or attached to sediments caused by erosion (Aubertot et al., 2007). This involves changing land use to reduce runoff or planting grass strips downstream the agricultural fields to filter runoff before it reaches the water system. Many authors have shown how grass strips can prevent pollution of surface water. Grass vegetation planted at the downstream edge of sloping field reduce runoff volume and velocity, by increasing hydraulic roughness of the soil surface, and subsequently by improving the infiltration rate (Le Bissonnais et al., 2004; Borin et al., 2005; Deletic and Fletcher, 2006). Decreasing flow volume and velocity lead to sediment deposition as a result of decreased transport capacity (Wu et al., 1999; Järvelä, 2002; Wilson et al., 2005). Barfield et al. (1979) and Dillaha et al. (1989) mentioned that 
102 sediment trapping can be substantial as long as the flow is shallow and uniform and the filter

103 is not submerged. Gumiere et al. (2011) reported that grass strips remove sediments and

104 pollutants from runoff by filtration, deposition, infiltration, adsorption, absorption, 105 decomposition, and volatilization.

106 In France, CORPEN (a collaborative organization gathering specialists from public 107 authorities and private organisations involved in agriculture and water protection) published 108 guidelines on how to identify the best locations for grass strips within catchments (CORPEN, 109 1997, 2003). Based on these guidelines, official French regulations were drawn up to 110 encourage farmers to establish PPC, including grass strips. According to French decree 2009111499 April 30, 2009, which took effect in 2010, the total surface area of PPC in each farm must 112 be at least $3 \%$ of the annual cropped area. PPC or grass strips must be planted within fields, 113 most importantly those bordering rivers, the strips must be between 5 to $10 \mathrm{~m}$ wide and must 114 cover at least $500 \mathrm{~m}^{2}$. These regulations apply at farm or field scale but do not account for the 115 hydrological processes at catchment scale. For example, the regulation concerning the width 116 of the grass strip does not take into account the size of the upper runoff area that induces the 117 quantity of runoff flow which have to be filtered (CORPEN, 1997). Moreover, ditches that 118 collect runoff water and flow into rivers will not be protected unless they are considered by 119 authorities as "water courses".

120 The design of AEM at catchment scale can be improved by modelling the processes involved 121 in runoff generation (flow concentration and soil erosion). Modelling the interactions between 122 physical characteristics and agricultural practices could help design adequate protective 123 measures (Ludwig et al., 2004). Gumiere et al. (2011) showed that only spatially distributed models account for the effects of the spatial organisation of land management practices on runoff and sediment transport. In such a context, distributed expert-based models are a possible solution (Evrard et al., 2009). The STREAM model (Sealing and Transfer by Runoff

127 and Erosion related to Agricultural Management; Cerdan et al., 2002a \& b) developed by 128 INRA (the French National Agronomic Research Institute) belongs to this family of expert129 based models.

130 Getting stakeholders actively involved in AEM implementation can be an efficient way to 131 proceed to design relevant, applicable and acceptable agri-environmental policy (Prager and 132 Freese, 2009; Roe García and Brown, 2009). In this way, the use of hydrologic models can 133 then help farmers collectively evaluate the impacts of their agricultural practices at the 134 catchment scale, and see which practices or protective measures are the most effective. To 135 support a participatory approach, Souchère et al. (2010) developed a role-playing game based 
136 on STREAM to raise the awareness of the different stakeholders (the mayor, farmers, rural and urban residents) about erosive runoff and the possibility of collective action.

138 The aim of this study is to verify that farmers can collectively discuss at the catchment scale about the impacts of their individual practices on erosive runoff and subsequently on surface water quality, and design appropriate AEM to reduce these impacts. In this way, we tested the STREAM model as a support for participatory approach: it was used to evaluate by comparisons the impacts of various management scenarios build with the farmers who cultivate the site and have to implement AEM. Farmers were actively involved in validating the model, building alternative scenarios, and analysing the model's response to the scenarios tested. Our study was carried out in the French Department Tarn et Garonne in collaboration with Lomagne district agricultural committee. Soil erosion is frequently observed in these catchments and sediment loads in streams and rivers have a direct negative impact on water quality (Lecomte, 1999; Riglos, 2005).

\section{MATERIAL AND METHODS}

\subsection{Study sites}

154 This study was conducted near the town Lavit de Lomagne in the Department Tarn et

155 Garonne (south-western France) with the active participation of the Lomagne district 156 agricultural committee ("Communauté de Communes de Lomagne Tarn et Garonnaise").

157 The Lomagne region, which spans the Departments of Tarn et Garonne and Gers, has a humid temperate climate: annual rainfall varies between 700 and $760 \mathrm{~mm}$ and average daily temperatures range from -10 to $35^{\circ} \mathrm{C}$. Rainfall is low to moderate in winter, and the most intense rainfall events occur in spring. Most soils at the two sites are silty loam, 'neoluvisol' according to the French classification, and 'excessively drained' according to the USDA soil drainage classification (USDA, 2003). Such soils are very susceptible to surface sealing

163 (CACG, 1965) because of their low clay (8-16\%) and organic matter (0.5- 1\%) contents.

164 These soil characteristics are similar to those used to calibrate and validate the STREAM model. The water table is very deep (more than 10 metres) and is therefore unlikely to generate saturation excess flow. The risk of erosive events is very high in April-May, when intense rainfall events (20-40 $\mathrm{mm}$ in only 2 or 3 hours) occur and many fields have just being cultivated or sown with spring crops and surface soil is bare or almost bare (less than $20 \%$ of 
Author- produced version ot the article published in Journal of Environmental Management, 2011, 96,76-85. The original publication is available at http://www.sciencedirect.com doi : 10.1016/j.jenvman.2011.11.001

169 vegetation cover) during this time period. These pedoclimatic conditions are common in 170 Southern Europa.

171 In collaboration with the local farmers, we selected two sites to (Fig. 1). The first site (site A; $43^{\circ} 58^{\prime} \mathrm{N}, 0^{\circ} 58^{\prime} \mathrm{E}$ ) is a 41 -ha hillside with slopes ranging from 0 to $15 \%$ comprising five

173 large fields cultivated by two farmers. In 2009, 36 ha were used for spring crops (maize and 174 sunflower) and 5 ha for winter wheat crop (Fig. 2a). The farmers suggested this site to study 175 how to reduce erosion because spring storm on just planted spring crops causes mud flows 176 that cover the downhill road nearly every year. The second site (site $\mathrm{B} ; 43^{\circ} 57^{\prime} \mathrm{N}, 0^{\circ} 56^{\prime} \mathrm{E}$ ) is a small 107-ha catchment that supplies the Serre River and comprises 40 fields cultivated by

178 five farmers. This site is characterised by a steep-sided upstream valley with strong slopes (more than 15\%) followed by a relatively flat valley (slope between 0 and 5\%). In 2009, five main crops were cultivated (Fig. 2b): winter crops (wheat, barley and rape) on $43 \%$ of the area, spring crops (maize, sunflower and sorghum) on $41 \%$, grasslands account for $12 \%$ of the area mainly in the upper basin, while forest and set-aside land account for less than $4 \%$ of the area.

\subsection{STREAM: hydrological model to simulate runoff and erosion}

STREAM is an expert-based model of runoff and erosion at the field/small catchment scale and at the rainfall event scale (Cerdan et al., 2002a \& b). It is spatially distributed and was developed under the ArcGis platform in the ArcObject language. This model is based on the basic hypothesis that soil surface properties are the major controlling factors for water runoff and soil erosion/redistribution processes in agricultural landscapes. Surface characteristics include soil roughness, surface crusting and vegetation cover evaluated at the field scale. It takes into account (i) the effects of soil surface characteristics (surface roughness and crusting) and vegetation cover to compute infiltration rates and soil surface erosion using expert rules, and (ii) tillage direction and landscape features (e.g. ditches, hedges, roads, developed sites) to build the runoff circulation network (Le Bissonnais et al., 1998). Input data are topography, field pattern and landscape features, soil surface state (roughness, crusting), vegetation cover ( $\%$ and type), and tillage direction determined at field scale, and, characteristics of the rainfall event (amount, duration and maximum intensity) and previous rainfall amount. In addition, STREAM model uses expert rules for determining runoff and erosion parameters. Moreover, STREAM has been developed to simulate the influence of 
Author- produced version ot the article published in Journal of Environmental Management, 2011, 96,76-85. The original publication is available at http://www.sciencedirect.com doi : 10.1016/j.jenvman.2011.11.001

203

204

205

206

207

208

209

210

211

212

213

214

215

216

tillage), and of introducing agri-environmental devices like grass strips (Cerdan et al., 2002a $\&$ b; Souchere et al., 2003b). Introduction of such devices is made adding new spatial objects with given infiltration capacities that replace the original ones in the fields. For instance, grass strips are spatial objects that enable an infiltration rate of $50 \mathrm{~mm} \cdot \mathrm{h}^{-1}$, as estimated by Cerdan et al. (2002b).

The model considers an infiltration/runoff balance for a single rainfall event characterised by the total amount of rainfall, its maximum intensity and rainfall duration. Water storage and runoff is computed for each pixel and accounts for soil infiltration as follows (Eq. 1):

Bir $=R-I R-\left(I_{\alpha} \cdot \square t\right)$

where Bir is the infiltration/runoff balance ( $\mathrm{mm}), R$ is the total rainfall event amount $(\mathrm{mm}), I R$ is residual water soil storage capacity after the previous rainfall $(\mathrm{mm}), I_{\alpha}$ is the steady state soil infiltration rate $\left(\mathrm{mm} \cdot \mathrm{h}^{-1}\right)$ and $t$ is the runoff event duration (h). Soil infiltration and water soil storage capacity are estimated from soil surface properties using a decision table that take into account the soil roughness (qualified in four classes according to the size of soil aggregates), the soil surface crusting (qualified in four classes, since fragmentary structure till sedimentary crust), and the vegetation cover (qualified in three classes according to the percentage of soil surface covered). Moreover, the water soil storage capacity decreases with an increase in the amount of previous rainfall. Consequently, the lower the residual water soil storage capacity, the quicker the soil becomes saturated; and once the soil is saturated, runoff occurs. Decision table for determining infiltration capacity in silty loam soils of Normandy with low clay and organic matter contents was established by Cerdan et al. (2002a \& b). Soils in site A and B having similar characteristics, we applied the same rules without modification. According to this decision table (Table 1), infiltration rate after previous rainfall of $10 \mathrm{~mm}$ varies between 5 and $10 \mathrm{~mm} \cdot \mathrm{h}^{-1}$ in site $\mathrm{A}$ and $\mathrm{B}$ according to the vegetation cover and soil surface properties (soil roughness in all fields was fixed to $1-2 \mathrm{~cm}$ ). The resulting runoff is routed at the catchment scale using a classical topographic runoff model (Jenson and Domingue, 1988) calculated at each pixel with a tool implemented in the ArcObject structure code. The flow direction is also modified by an algorithm (Souchère et al., 1998) so that runoff can follow the main linear direction in the landscape, such as the ditch and tillage directions in the fields. Flow accumulation at the catchment scale is calculated taking into account the runoff flow network and the balance infiltration-runoff of each cell (Cerdan et al., 2002a). 
The considered erosion processes are water erosion, including both rill and interrill erosion. Interrill erosion includes hillslope processes referred to as mass translocation by runoff, in which water flow is responsible for the remobilisation of soil particles detached by splash erosion. In the model, this evaluation comes from an empirical analysis of the soil surface properties based on rainfall and runoff field observations (Cerdan et al., 2002a). A decision table based on soil surface properties (vegetation cover, soil roughness and soil crusting) and maximum rainfall intensity is used to estimate the sediment concentration $\left(\mathrm{S}_{\mathrm{c}}\right)$ in runoff. We used expert rules established by Le Bissonnais et al. (2005) for determining sediment concentration in silty loam soils with low clay and organic matter contents (see Table 1). Sediment delivery for each pixel is then calculated integrating sediment concentration with the runoff volume.

Rill erosion module is based on an empirical relationship between soil surface properties, slope, simulated flow accumulation and observed rill sections as developed by Souchère et al. (2003a). The sensitivity to rill erosion $\left(S_{r e}\right)$ is calculated as follow (Eq. 2):

253 where $F$ and $C$ represent the class factors "friction" and "cohesion" relying to land cover and soil surface roughness, $A$ is the effective cumulated runoff in the pixel $\left(\mathrm{m}^{3}\right)$, and $S\left(\mathrm{~m}_{\mathrm{m}} \mathrm{m}^{-1}\right)$ is the local slope. The original rill identification procedure considers also some flow thresholds (i.e. minimum drainage area, 0.6 ha; minimum flow segment length, $80 \mathrm{~m}$ ) able to generate incipient gully conditions as hypothesized for some small agricultural catchments in France (Ludwig et al., 1996). Finally, rill erosion $\left(R_{s}, \mathrm{~kg}\right)$ is linked to the sensitivity factor by an empirical relationship (Ludwig et al., 2005) as follow (Eq. 3):

261 where $\rho$ is the soil bulk density $\left(\mathrm{kg} \cdot \mathrm{m}^{-3}\right), \lambda$ is the pixel dimension (m), and $k_{s}$ represents a 262 calibration coefficient to estimate the rill section $\left(\mathrm{m}^{2}\right)$ on each pixel along the runoff network. 263 The resulting rill section is converted in soil loss volume on the base of the pixel dimension.

264 Both rill and interrill erosion modules are sediment transport limited, with the maximum sediment concentration controlled by several threshold functions with respect to the local topography and soil cover, including vertical curvature (concavity $>0.055 \mathrm{~m}^{-1}$ ), slope gradient $\left(<0.02 \mathrm{~m} \cdot \mathrm{m}^{-1}\right)$, soil use type and soil cover $(>60 \%)$, after applying concentration limits ranging from 2.5 to $10 \mathrm{~g} \mathrm{l}^{-1}$ (Cerdan et al., 2002a). 
Author- produced version ot the article published in Journal of Environmental Management, 2011, 96,76-85. The original publication is available at http://www.sciencedirect.com doi : 10.1016/j.jenvman.2011.11.001

To simulate the accumulation of runoff flow and erosion, we used a reference rainfall of a one-year return period based on the Montana formula which gives the rainfall intensity as a function of time (Eq. 4):

$q_{r}=a \cdot t^{-b}$

where $q_{r}$ is the rainfall intensity (mm.h-1), $t$ is the duration of event (h), and $a$ and $b$ are specific site parameters corresponding to the intensity-duration curve for the one-year return period. Basing on this equation, we computed a reference rainfall event following the method used by Taky et al. (2009). The resulting hyetograph corresponded to a daily spring rainfall event of $25 \mathrm{~mm}$, with a maximum intensity of $40 \mathrm{~mm} \cdot \mathrm{h}^{-1}$ and a duration of 2 hours. The previous rainfall amount (cumulated rainfall during the preceding 48 hours) was set at $10 \mathrm{~mm}$. According to the farmers, this type of storm event occurred almost every year. For example in 2009 on site A, eroded soil filled the ditches, a mudslide blocked the downhill road and a bulldozer was needed to clear it, the mayor was threatening to make the farmers pay for clearing the road. The sediments deposited downslope destroyed spring crop seedlings, and the affected areas had to be replanted. The sediments (with adsorbed pesticides) flowed to the river via a network of ditches thereby polluting surface water.

Validating a STREAM model requires measures of runoff and sediment yield amounts. Such measures on both sites did not exist, and we used decision tables which were built and validated for same soils and same crops. Moreover our aim with the models was not to obtain an accurate estimation of runoff and sediment yield amounts on both sites, but to support discussion between farmers about options to manage it. Following other participative modelling and simulating approaches (Bellon, 2001; Antunes et al., 2006; Bécu et al., 2008; Jankowski, 2009), qualitative model validation was devoted to the farmers who are used to observe runoff and erosion in their fields. Moreover, we analysed the impacts of scenarios by comparison in the simulated results and considering only big differences.

\subsection{Participative approach supported by simulations with STREAM}

Participatory approaches concern many situations in decision making, notably natural resources management (Wondolleck and Yaffe, 2000) or integrated water resource management (Pahl-Wostl et al., 2007), from local (e.g. Bécu et al., 2008) to large (e.g. De Stefano, 2010) scales, and involve stakeholders with various forms: from information, to consultation, to designing policy, to shared decision making (Hare et al., 2003). Participative 
Author- produced version ot the article published in Journal of Environmental Management, 2011, 96,76-85. The original publication is available at http://www.sciencedirect.com doi : 10.1016/j.jenvman.2011.11.001

304 approaches frequently involve the use of simulation models that provide evaluation of management options (Bots and van Daalen, 2008). Here, we used the simulation STREAM model as a support for a participatory approach with farmers to discuss possible ways to prevent erosive runoff (and hence to avoid the risk of river pollution) at both sites. This approach combined 3 steps: (i) assessing the risk of erosive runoff due to current agricultural practices, (ii) testing the impact of possible changes to mitigate erosive runoff risks, and (ii) discussing their feasibility. The farmers were encouraged to play an active role in the decisions affecting their catchment, to interactively explore alternative practices, and to discuss economic and technical constraints/assets that winder or encourage their adoption. Five meetings with farmers took place between January and June 2009. The two first meetings were with the Lomagne district agricultural committee to choose the sites. Site A (the hillside) was chosen because erosive runoff is severe and occurs almost every year in spring. Site B (the catchment) was chosen because it is small and different crops are grown there. Another important aspect was that most of the farmers ( 5 of 6 ) at the two sites agreed to spend time with us working on erosive runoff and surface water pollution. The third meeting in early May 2009, was spent visiting the sites with most of the farmers to record cropping practices and the state of the surface soil. The fourth and fifth meetings $(2$ successive evenings in June 2009), which all the 5 farmers attended, were spent (i) qualitatively validating the simulated runoff network, (ii) building scenarios for the two sites including alternative locations of grass strips and/or changes in cropping patterns, and (iii) analysing the simulated impacts of changes.

The STREAM model was first run using the crops and soil surface states recorded at each site during the first visit. These "original scenarios" (A0 and B0) were used to validate qualitatively the simulation models: the farmers compared simulated and observed (in the past) runoff pathways and erosion-accumulation rates. The model scenarios were then used as support for discussions among farmers about the system to be managed and to explore possible changes to prevent erosive runoff. Scenarios A0 and B0 (see fig. 2) were used at each site as benchmark and the simulated results of changes were evaluated by comparing them 332 with this scenario.

333 Analysis of scenarios A0 and B0 led to suggestions for several changes to prevent erosive 334 runoff: two scenarios (A1 and A2) for site A and three scenarios (B1, B2 and B3) for site B. 335 Two kinds of management options were discussed: (i) grass strips inside or on border of 336 fields, or grassland fields to slow down runoff and enable it to infiltrate; (ii) changes in the cropping pattern knowing runoff and erosion on spring crops are higher than on winter crops. 
338 For the hillside at site A, proposals concerned only the location and dimensions of grass strips

\subsection{Reducing erosive runoff on the hillside at site A}


With the existing cropping pattern and soil surface state (scenario A0), simulated total runoff for one rainfall event reached $3116 \mathrm{~m}^{3}$, and 335 metric tons of soil were lost (Table 2). Taking into account the area of site A (41 ha), these total amounts corresponded to $76 \mathrm{~m} 3$ of water and 8 tons of soil per hectare. A simulated map of spatial runoff and which soil was lost. Farmers confirmed that patterns matched well their observations made in the past in their fields, notably with great runoff paths and erosion scratches. Soil losses and erosion (Fig. 5) showed the water pathway and the main locations at sediment transport deriving from runoff flow, erosion pathway is therefore very similar to runoff pathway as shown in figure 5 .

Planting 5m width grass strips bordering ditches and roads (scenario A1) reduced runoff by about $46 \%$ and sediment yield by $26 \%$ (Table 2). Runoff and erosion were not prevented in the fields, but grass strips partially retained the flows of water and sediments before they reached the ditches. When 10-m wide grass strips were planted where the slope was steepest or at mid-slope in the fields (scenario A2), runoff was reduced by $43 \%$, and sediment yield by $39 \%$. Scenario A2 was thus more efficient than scenario A1 for preventing to mud flows on the road, and soil losses in the fields were also reduced. Efficiency of grass strips depend therefore on its location: (i) grass strip has better efficiency when it is located on runoff flow pathway; (ii) it enable soil sedimentation when it is located downstream (by filtering the runoff water highly concentrated with soil sediment); (iii) it prevent from soil wrenching when it is located upstream (by reducing/slowing down the runoff flow).

Farmers are already used to planting grass strips as shown in scenario A1. They agreed that grass strips had a beneficial impact on runoff and on the simulated results of scenario A1, but said that sediments accumulated in the grass strip and did not want to install wider ones. Planting a grass strip means reducing the size of field and, in addition, creates a problem because tractors are not allowed on the strip to prevent soil compaction, which decreases infiltration rate. Most of the farmers (3 of 5) did not like scenario A2. Planting grass strips in the middle of fields is thus more problematic than at the edge. What is more, most farmers initially failed to understand how grass strips planted mid-slope could reduce erosive runoff. One farmer provided the explanation: due to the slope, water flows faster and planting grass strips in the field slows runoff down before it becomes erosive.

\subsection{Reducing runoff in the catchment at site B}


With the existing cropping pattern and soil surface state (scenario B0), total simulated runoff volume reached $3249 \mathrm{~m}^{3}$ and 241 metric tons of soil were lost (Table 2). Like for site A, farmers confirmed the pathways of the main simulated runoff flows (Fig. 6) compared well with flows in their fields. Especially, runoff accumulation in fields on the right river bank in the western part of the catchment (see Fig. 6a), explained why two farmers had decided to use them as set aside land or grassland. Nevertheless, one field, cultivated by a third farmer, was still being cultivated with sorghum (a spring crop). Moreover, the upstream basin (western from set aside field long the river) produced about the half of total sediment yield (see Fig. $6 \mathrm{~b})$. Taking into account the area of site B (107 ha), these total amounts corresponded to 30 $\mathrm{m} 3$ of water and 2 tons of soil per hectare, i.e. 2.5 and 4 times less than in site A. Greater proportion of covered soil and also weaker average slope in site B explained this difference.

A map was created identifying fields that contributed most to runoff along with those that collected runoff. By comparing figure $6 \mathrm{a}$ (runoff pathways) and figure $2 \mathrm{~b}$ (existing cropping pattern and land use), farmers concluded that the main runoff started in fields planted with spring crops and the reasons were discussed collectively. In fields that are cultivated in spring, vegetation covers less than $20 \%$ of the soil surface. When intense rainfall strikes unprotected soil with low structural stability, runoff occurs, and when runoff accumulates on bare soil, erosion occurs. Soil sediments transported by runoff then pollute the river. Conversely, grassland and winter crops do not generate runoff and help slow down water flows from uphill fields. Winter crops completely cover the soil surface thus protecting it from the

In scenario B1, except in grassland and set aside fields, grass strips were planted bordering the rivers, in accordance with official regulations. This resulted in a reduction of more than $50 \%$ in runoff and sediment yield (Table 2). The sloping upstream basin at site A contributed a lot in the total sediment yield (see sediment yield pathway on fig. 6b). Installation of grass strips on the left bank and grassland on the right bank of the river in the upstream basin resulted in a strong reduction of sediment yield. For the farmers, this result confirmed the usefulness of grass strips in protecting rivers from pollution. However, official regulations do not make it obligatory to plant grass strips in small fields, of which there were many on both river banks. 
438 The reallocation of winter and spring crops in the catchment (scenario B2) achieved a slightly lower reduction in sediments yield (46\%), but runoff was only reduced by $22 \%$ (Table 2 ). In this scenario, winter crops were preferentially planted in fields bordering the rivers. Taking into account the crop rotation over years, this scenario induced to select in these fields only winter crop rotations (e.g. rape with wheat and barley). Winter cropped fields bordering the river retained the soil sediments to the same extent as grass strips and protected the rivers.

444 Spring crops were planted in uphill fields where the slopes were slightly steeper than in 445 downhill fields, thus increasing runoff. However, grass strips reduce the size of the field and consequently the farmers' income. In scenario B2, redistributing spring and winter crops did not affect the farmers' income. Exchanging fields between farmers is possible but not easy because crop rotations need to be taken into account: spring crop like maize, sorghum and sunflower, are often cultivated alternately with winter crops like wheat and barley. In addition, the farmers said that they preferred using downhill fields for spring crops, which produce more income than winter crops. The farmers consider downhill soils to be deeper and more fertile, and to enable higher yields with less irrigation and fertilisation. This is in accordance with soil being eroded in uphill fields and soil sediment accumulating in downhill

454 fields.

In scenario B3, all the fields were well covered by vegetation of winter crops, and runoff and erosion almost completely stopped (Table 2). However, the farmers did not agree with this cropping plan because it would lead to a major reduction in their income: in 2005, the income from maize and sunflower ranged from $€ 541$ to $€ 1025$ per hectare, while the income from winter wheat and rape ranged from $€ 508$ to $€ 618$ per hectare (Table 3). But this income depends also on prices of agricultural products that can strongly vary between years (for instance, prices in 2007 was about the double). In addition, farmers confirmed that alternating spring and crops enabled better pest and weed control (Macé et al., 2007). In fact they only accepted trying this scenario to evaluate its impact on runoff and erosion. As the results of the simulation demonstrated the major impact spring crops have on erosion, the farmers were willing to discuss this drastic solution in catchments where erosion is a very serious constraint. 
Even though STREAM model requires a lot of input parameters, especially for decision tables, these parameters are quite simple and easy to inform with farmers. Nevertheless, it requires to know soil surface state and vegetation type and cover in each plot, and decision table suppose to have measures on infiltration capacity and potential interrill and rill erosion for each kind of plot according to soil, vegetation cover and topography. Here, in one hand, we could know the parameters for each field because both sites are very small; to obtain a global view of a larger territory, it would be necessary to adapt STREAM to incorporate remote-sensing data instead of field data (Souchère et al., 2005); the feasibility of this upscalling has been demonstrated by King et al. (2005). In the other hand, we used decision tables established by Cerdan et al. (2002b) and Le Bissonnais et al. (2005) for silty soils of Normandy, assuming that runoff and erosion processes are similar because soils and vegetation covers have same characteristics.

Mapping land use, cropping patterns, and simulation results were the key points to engage with farmers. All discussions among the farmers were based on the maps that were created to validate runoff pathways and to locate grass strips and crops. This confirms that geographical information systems (GIS) are a good support for participatory approaches in many sectors, as reported by many authors (e.g. Repetti and Prélaz-Droux, 2003; De Freitas and Tagliani, 2009; Jankowski, 2009; Lagabrielle et al., 2010).

Most farmers are aware that their practices have an impact on the environment, especially on water quality and quantity, but not all of them are ready to change (Michel-Guillou and Moser, 2006). In our case, the farmers knew that bare soil and along-slope tillage increase the risk of erosion. We did not try to test the effect of changing the direction of tillage because (i) our model had not been validated for it, and (ii) because farmers did not want to change tillage direction in sloping fields as across-slope tillage is impossible and even dangerous (risk of overturn) when slope exceeds $10 \%$. Nevertheless, it is a fact that in downslope and less steep fields, across-slope tillage slows downhill runoff (Basic et al., 2001). Despite this knowledge, farmers base their choice on the geometry of the field and aim to minimize turns, which not only increase work time but also soil compaction. Choosing tillage direction is thus an economic choice like choosing between winter and spring crops. Spring crops imply bare soils in winter and at the beginning of spring. The European Common Agricultural Policy encourages the cultivation of a catch crop in the intercropping period to prevent nitrate leaching and erosive runoff during winter. The catch crop then has to be ploughed under at 
Author- produced version ot the article published in Journal of Environmental Management, 2011, 96,76-85. The original publication is available at http://www.sciencedirect.com doi : 10.1016/j.jenvman.2011.11.001

505 cultivating catch crops in plots with silty loam soil because ploughing this soil in the wet conditions typical of the beginning of spring generated big clods that make it impossible to obtain a suitable seedbed for the following spring crop.

508 Direct seeding spring crops into mulch (crop residues or cover crop) could also be an option to prevent the risk of erosion (Holland, 2004; Lobb et al., 2007). Farmers did not choose to test this option because this topic was burning and divided the farmers in the Tarn and Garonne department. Nevertheless, they accepted to discuss this option after the simulation of scenarios. Impacts of direct seeding in mulch system on runoff and yield sediment could indeed be compared with scenarios B2 or B3, because mulch covers soil for more than $60 \%$ as in winter cropped fields. Farmers agreed with this comparison and the beneficial impacts of direct seeding, but they claimed this option presents two major constrains: (i) it is devoted to large cropping area because it needs high cost drilling machine, and (ii) it is risky in this type of soil because results (yield and cultivation cost) are very variable/unpredictable, as observed by Ball et al. (1994) on imperfectly drained loamy soils.

Fields cultivate with spring crops are the main source of erosive runoff. This observation has led some mayors in France (e.g. Ettendorf in Alsace) to issue an order limiting spring crop acreage in their municipality and obliging farmers to come up with a collective cropping plan. The farmers in our study were not firmly opposed to the limitation of spring crop acreage: they were prepared to accept the resulting drop in income as a way of preventing erosive runoff. But they pointed out that a collective cropping plan was not easy to set up for several reasons. Crop history has to be taken into account in the choice of the crop, and soil fertility is not homogenous within the catchment and thus has an impact on inputs and yield. Designing a collective cropping plan thus requires discussion between neighbours. Coordination is even more difficult when farmers rent fields.

In our study, all the farmers were aware of the effect of erosion on soil fertility. Several decades after land consolidation, they see top soil has been lost from sloping fields (Bruno and Fox, 2004). However, the farmers said that they could easily (and cheaply) compensate for the annual effect of soil erosion on crop yield though fertilisation, and that they preferred to cultivate crops with high potential (i.e. maize) in downhill fields because these fields were more fertile. By the end of the study, farmers had not changed their practices or done anything to stop the process of erosion in their own fields. By using the hydrological model, the 
preserve water quality by preventing pollution by soil sediments resulting from erosive runoff, but do not stop soil losses within fields. Stopping erosion requires reducing runoff accumulation especially in large sloping fields. In this kind of field, planting grass strips inside the field rather than on the border can prevent both erosion and water pollution

\section{3 by soil sediments.}

544 Farmers' practices are based on economic choices that take into account many different issues

545 (Greiner et al., 2009). As is true for other economic agents, farmers consider short-term 546 income before long-term income and are more likely to consider impacts that are easy to evaluate in monetary terms. Changing their practices to reduce the impact of their activities on the environment is not a priority for farmers (Marsh, 1977). CAP regulations base payment of EC subsidies upon compliance of environmental practices. Non-compliance of environmental rules is penalised by a reduction of direct subsidies to farm income. Reduction rate is fixed generally between 1 and $5 \%$, very occasionally $20 \%$, according to the level of fault and its intentional character (Ministère de l'Agriculture et de la Pêche, 2009). The proportion of EC subsidies into farm income varies considerably with the farming system (Blogowski and Chatellier, 2004): EC aids to farm comprise subsidy "coupled" to the production depending on its current cropping pattern (see Table 3), and decoupled income support depending its production activity in the past. Penalties are therefore different according to the part of EC subsidies in farm income. Moreover, penalties need to be compared with the economic gain resulting from the non-respect of environmental regulation.

\section{CONCLUSION}

STREAM was successfully used to simulate the impact of different agri-environmental scenarios on runoff and yield sediment in both studied sites. It could then serve as a decision support tool to design options for controlling runoff and erosion. The model framework is hence applicable in others sites, but decision rules that determine infiltration rate, and rill and interrill erosion need to be adapted to the local context by combining plot, field and catchment measurements and observations.

568 Using a hydrological model, based on spatial input data and simulated results, with farmers could be a useful way to discuss ways of preventing the impact of agriculture on the environment and to design management options of erosive runoff at the field and catchment scales. But this approach is costly and time consuming and consequently cannot be used in all catchments in a given region. However, models on selected catchments where the risk of 
erosive runoff is high could provide useful information for farmers, advisors, managers about designing water and soil conservation issues at the catchment scale. The selection of catchments should be based on several criteria, especially land use, slopes, plot size and soil type (IFEN, 1998; Riglos, 2005), and could be based also on the experience of local stakeholders (farmers, watershed and river managers, mayors...). Case studies at these selected sites would generate different proposals on how to control erosive runoff. These proposals, adapted to local and regional contexts, could be useful to policy makers in drawing up relevant agro-environmental measures. In this way, local district committees like in Lomagne, and chambers of agriculture, from department to region, could have major roles.

Our case study also showed that changing the cropping pattern currently used in the catchment would be at least as efficient as planting grass strips in reducing mud flows and surface water pollution. Such changes require coordination between farmers and imply that the farmers (i) are aware of the impact of their practices on the environment, (ii) are willing to change their practices, and (iii) consult their neighbours. A role-playing game developed by Souchère et al. (2010) pointed to the need for coordination between the different agents living in the same area: farmers, rural and urban residents, and the mayor of the commune concerned. This kind of game could also be used with farmers in a typical catchment to simulate current runoff situations and to test different solutions to prevent erosion and surface water pollution. According to Prager and Freese (2009), results of simulations with stakeholders directly concerned by agro-environmental policy could then be used to draw up official regulations at regional scale.

\section{Acknowledgements}

This study was carried out in the framework of a research programme entitled "Which agricultural systems and which public policies for sustainable management of water resource? Tools and methods for territorial governance" and was funded by the French National Research Agency (ANR). The authors wish to thank all the farmers of the agricultural committee of the Lomagne district (CCLTG) who contributed to this work.

\section{REFERENCES}


Author- produced version ot the article published in Journal of Environmental Management, 2011, 96,76-85. The original publication is available at http://www.sciencedirect.com doi : 10.1016/j.jenvman.2011.11.001

606

607

608

609

610

611

612

613

614

615

616

617

618

619

620

621

622

623

624

625

626

627

628

629

630

631

632

633

634

635

636

637

Antunes, P., Santos, R., Videira, N., 2006. Participatory decision making for sustainable development - the use of mediated modelling techniques. Land Use Policy 23 (1): 4452 .

Aubertot, J.N., Barbier, J.M., Carpentier, A., Gril, J.J., Guichard, L., Lucas, P., Savary, S., Voltz, M. (Eds), 2007. Pesticides, agriculture et environnement. Réduire l'utilisation des pesticides et en limiter les impacts environnementaux. Quae, Versailles (France), $119 \mathrm{pp}$.

Ball, B.C., Lang, R.W., Robertson, E.A.G., Franklin, M.F., 1994. Crop performance and soil conditions on imperfectly drained loams after 20-25 years of conventional tillage or direct drilling. Soil \& Tillage Research 31 (2-3): 97-118.

Barfield, B. J., Tollner, E. W., Hayes, J. C., 1979. Filtration of sediment by simulated vegetation I. steady-state flow with homogenous sediment. Trans. ASAE 22 (3), 540-548.

Basic F., Kisic, I., Butorac, A., Nestroy, O., Mesic, M., 2001. Runoff and soil loss under different tillage methods on Stagnic Luvisols in central Croatia. Soil \& Tillage Research 62 (3-4): 145-151

Bécu, N., Neef, A., Schreinemachers, P., Sangkapitux, C., 2008. Participatory computer simulation to support collective decision-making: Potential and limits of stakeholder involvement. Land Use Policy 25 (4): 498-509.

Bellon, M.R., 2001. Participatory Research Methods For Technology Evaluation: A Manual for Scientists Working with Farmers. Human Ecology 34:249-273.

Blogowski, A., Chatellier, V., 2004. Les aides directes aux exploitations agricoles européennes et françaises depuis la réforme de 1992. In Butault, J.P. (Ed): Les soutiens à l'agriculture. Théorie, histoire, mesure. Quæ, «Mieux comprendre», Versailles (France), ISBN 9782738011763, pp 223-275.

Boardman, J., Ligneau, L., De Roo, A., Vandaele, K., 1994. Flooding of property by runoff from agricultural land in northwestern Europe. Geomorphology 10: 183 - 196

Borin, M., Vianello, M., Morari, F., Zanin, G., 2005. Effectiveness of buffer strips in removing pollutants in runoff from a cultivated field in north-east Italy. Agriculture, Ecosystems \& Environment 105, 101-114.

Bots, P.W.G., van Daalen, C.E., 2008. Participatory Model Construction and Model Use in Natural Resource Management: a Framework for Reflection. Systemic Practice and Action Research 21 (6): 389-407 
Author- produced version ot the article published in Journal of Environmental Management, 2011, 96,76-85. The original publication is available at http://www.sciencedirect.com doi : 10.1016/j.jenvman.2011.11.001

Bruno, J.F., Fox, D., 2004. L'érosion en rigoles dans les côteaux du Sud-Ouest. In Monestier, P., Lardon, S., Séguin, B. (Eds.): Organisation spatiale des activités agricoles et processus environnementaux. INRA Editions, Versailles (France), pp 13-26.

CACG (Ed .), 1965. Etudes pédologiques de reconnaissance au 1/50 000 : St-Nicolas de la Grave-Verdun sur Garonne-Neste, Petites Pyrénées et terrasses de St-Lys. Compagnie d'Aménagement des Côteaux de Gascogne (CACG), Tarbes (France). .

Cerdan, O., Le Bissonnais, Y., Souchére, V., Martin, P., Lecomte, V., 2002a. Sediment concentration in interill flow: interactions between soil surface conditions, vegetation and rainfall. Earth Surface Processes and Landforms 27: 193-205.

Cerdan, O., Souchére, V., Lecomte, V., Couturier, A., Le Bissonnais, Y., 2002b. Incorporating soil surface crusting processes in an expert-based runoff model STREAM. CATENA 46: 189-205.

Chamber of Agriculture Midi-Pyrénées, 2006. Références technico-économiques en systèmes de grandes cultures. Résultats 2005. Conseil Régional Midi-Pyrénées / CasDAR, 31 pp (available : http://www.mp.chambagri.fr/IMG/pdf/ref_tech_eco_gc2005.pdf).

Comité de bassin Adour-Garonne, 2004. Etat des lieux du district Adour-Garonne. Agence de l'eau Adour-Garonne, $180 \mathrm{pp}$.

CORPEN (Ed.), 1997. Produits phytosanitaires et dispositifs enherbés. Etat des connaissances et propositions de mise en ouvre. CORPEN, Groupe dispositifs enherbés, Paris, $78 \mathrm{p}$.

CORPEN (Ed.), 2003. Des indicateurs pour des actions locales de maîtrise des pollutions de l'eau d'origine agricole : éléments méthodologiques - application aux produits phytosanitaires. CORPEN, Paris, $136 \mathrm{p}$.

De Freitas, D.M., Tagliani, P.R., 2009. The use of GIS for the integration of traditional and scientific knowledge in supporting artisanal fisheries management in southern Brazil. Journal of Environmental Management 90 (6): 2071-2080.

Deletic, A., Fletcher, T. D., 2006. Performance of grass filters used for stormwater treatment a field and modelling study. J. of Hydrology 317 (3-4), 261-275.

De Stefano, L., 2010. Facing the water framework directive challenges: A baseline of stakeholder participation in the European Union. Journal of Environmental Management 91 (6): 1332-1340.

Dillaha, T. A., Reneau, R. B., Mostaghimi, S., Lee, D., 1989. Vegetative filter strips for agricultural nonpoint source pollution-control. Trans of ASAE 32, 513-519. 
Evrard, O., Cerdan, O., Wesemael, B., Chauvet,M., LeBissonnais, Y., Raclot, D., Vandaele, K., Andrieux, P., Bielders, C., 2009. Reliability of an expert-based runoff and erosion model: Application of STREAM to different environments. CATENA 78(2): 129-141.

Greiner, R., Patterson, L., Miller, O., 2009. Motivations, risk perceptions and adoption of conservation practices by farmers. Agricultural Systems 99 (2-3): 86-104.

Gumiere, S. J., Le Bissonnais, Y., Raclot, D., Cheviron, B., 2011. Vegetated filter effects on sedimentological connectivity of agricultural catchments in erosion modelling: A review. Earth Surface Processes and Landforms 36, 3-19.

Hare, M., Letcher, R. A. , Jakeman, A. J., 2003. Participatory natural resource management: a comparison of four case studies. Integrated Assessment 4(2):73-78.

Holland,J.M., 2004. The environmental consequences of adopting conservation tillage in Europe: reviewing the evidence, Agriculture, Ecosystems \& Environment 103: 1-25.

IFEN (Ed.), 1998. Cartographie de l'aléa « Erosion des Sols » en France. Institut Français de l'Environnement (IFEN), collection «Etudes et Travaux », $\mathrm{n}^{\circ} 18,78 \mathrm{pp}$.

Jankowski, P., 2009. Towards participatory geographic information systems for communitybased environmental decision making. Journal of Environmental Management 90 (6): 1966-1971.

Järvelä, J., 2002. Flow resistance of flexible and stiff vegetation: a flume study with natural plants. Journal of Hydrology 269, 44-54.

Jenson, S.K., Domingue, J.O., 1988. Software tools to extract topographic structure from digital elevation data for geographic information system analysis. Photogrammetric Engineering and Remote Sensing 54 (11): 1593-1600.

Lagabrielle, E., Botta, A., Daré, W., David, D., Aubert, S., Fabricius, C., 2010. Modelling with stakeholders to integrate biodiversity into land-use planning - Lessons learned in Réunion Island (Western Indian Ocean). Environmental Modelling \& Software 25 (11): 1413-1427.

Le Bissonnais, Y., Benkhadra, H., Chaplot, V., Fox, D., King, D., Daroussin, J., 1998. Crusting, runoff and sheet erosion on silty loamy soils at various scales and upscaling from $\mathrm{m}^{2}$ to small catchments. Soil \& Tillage Research 46: 69-80.

Le Bissonnais, Y., Lecomte, V., Cerdan, O., 2004. Grass strip effects on runoff and soil loss. Agronomie 24 (3), 129-136.

Le Bissonnais, Y., O. Cerdan, V. Lecomte, H. Benkhadra, V. Souchère, P. Martin (2005). Spatial and temporal variability of soil surface characteristics influencing infiltration, runoff and interrill erosion of cultivated fields. Catena, 62(2-3): 111-124. 
Author- produced version ot the article published in Journal of Environmental Management, 2011, 96,76-85. The original publication is available at http://www.sciencedirect.com doi : 10.1016/j.jenvman.2011.11.001

Lecomte, J., 1999. Réflexions sur la naturalité. Courrier de l'environnement de l'INRA, 37: 610 .

Lobb, D.A., Huffman, E., Reicosky, D.C., 2007. Importance of information on tillage practices in the modelling of environmental processes and in the use of environmental indicators. Journal of Environmental Management 82 (3): 377-387.

Ludwig, B., Auzet, A.V., Boiffin, J., Papy, F., King, D., Chadoeuf, J., 1996. États de surface, structure hydrographique et érosion en rigole de bassins versants cultivés du Nord de la France. Étude et Gestion des Sols 3 (1) : 53-70.

Ludwig, B., Le Bissonnais, T., Souchère, V., Cerdan, O., Jetten, V., 2004. Intégration des pratiques agricoles dans la modelisation du ruissellement et de l'erosion des sols : Les modeles LISEM et STREAM. In Monestiez, P., Lardon, S., Seguin, B. (Eds): Organisation des activités agricoles et processus environnementaux. Sciences Update, Editions INRA, Versailles (France), pp 43-62.

Macé, K., Morlon, P., Munier-Jolain, N., Quéré, L., 2007. Time scales as a factor in decisionmaking by French farmers on weed management in annual crops. Agricultural Systems 93 (1-3): 115-142.

Marsh, J.S., 1977. The policy approach to sustainable farming systems in the EU. Agriculture, Ecosystems \& Environment 64 (2): 103-114.

Michel-Guillou, E., Moser, G., 2006. Commitment of farmers to environmental protection: From social pressure to environmental conscience. Journal of Environmental Psychology 26 (3): 227-235.

Ministère de l'Agriculture et de la Pêche, 2009. Conditionnalité 2009 - Introduction générale. $\quad 8 \quad$ pp. (http://draf.nord-pas-decalais.agriculture.gouv.fr/IMG/pdf/conditionnalite_2009___introduction_cle08483c.pdf) Nearing, M.A., Jetten, V., Baffaut, C., Cerdan, O., Couturier, A., Hernandez, M., Le Bissonnais, Y., Nichols, M.H., Nunes, J.P., Renschler, C.S., Souchere, V., van Oost, K., 2005. Modeling response of soil erosion and runoff to changes in precipitation and cover. CATENA 61(2-3): 131-154.

Pahl-Wostl, C., Sendzimir, J., Jeffrey, P., Aerts, V., Berkamp, G., Cross, K., 2007. Managing change toward adaptive water management through social learning. Ecology \& Society 12(2): 30. (http://www.ecologyandsociety.org/vol12/iss2/art30/).

Papy F., Douyer C., 1991. Influence des états de surface du territoire agricole sur le déclenchement des innondations catastrophiques. Agronomie, 11 (3):.201-215. 
Author- produced version ot the article published in Journal of Environmental Management, 2011, 96,76-85. The original publication is available at http://www.sciencedirect.com doi : 10.1016/j.jenvman.2011.11.001

Prager, K, Freese, J., 2009. Stakeholder involvement in agri-environmental policy making Learning from a local- and a state-level approach in Germany. Journal of Environmental Management 90 (2): 1154-1167.

Probst, J.L., 1985. Nitrogen and phosphorus exportation in the Garonne Basin (France). Journal of Hydrology 76 (3-4): 281-305.

Repetti, A., Prélaz-Droux, R., 2003. An Urban Monitor as support for a participative management of developing cities. Habitat International 27 (4): 653-667.

Riglos, O., 2005. Cartographie du risque potentiel de pollution diffuse des eaux de surface par les produits phytosanitaires et transfert d'échelle spatiale d'un indicateur agroenvironnemental sur des bassins versants emboîtés de la Save (Gers). Mémoire d'ingénieur, ESAP (Toulouse) / Cemagref (Bordeaux), 132 pp.

Robert, A., 2000. The Common Agricultural Policy. Sheffield Academic Press, Sheffield (UK), ISBN 1-84 127.126-8.

Roe Garcia, C.E., Brown, S., 2009. Assessing water use and quality through youth participatory research in a rural Andean watershed. Journal of Environmental Management 90 (10): 3040-3047.

Souchère, V., King, D., Daroussin, J., Papy, F., Capillon, A., 1998. Effect of tillage on runoff directions : consequences on runoff contributing area within agricultural catchments. Journal of Hydrology 206: 256-267.

Souchère, V., Cerdan, O., Ludwig, B., Le Bissonnais, Y., Couturier, A., Papy, F., 2003a. Modelling ephemeral gully erosion in small cultivated catchments. CATENA 50 (2-4): 489-505.

Souchère, V., King, C., Dubreuil, N., Lecomte-Morel, V., Le Bissonnais, Y., Chalat, M., 2003b. Grassland and crop trends: role of the European Union Common Agricultural Policy and consequences for runoff and soil erosion. Environmental Science \& Policy 6 (1): 7-16.

Souchère, V., Cerdan, O., Dubreuil, N., Le Bissonnais, Y., King, C. 2005. Modelling the impact of agri-environmental scenarios on runoff in a cultivated catchment (Normandy, France). CATENA 61 (2005) 229-240.

Souchère, V., Millair, L, Echeverria, J., Bousquet, F., Le Page, C., Etienne, M., 2010. Coconstructing with stakeholders a role-playing game to initiate collective management of erosive runoff risks at the watershed scale. Environmental Modelling \& Software 25 (11): 1359-1370. 
Author- produced version ot the article published in Journal of Environmental Management, 2011, 96,76-85.

The original publication is available at http://www.sciencedirect.com doi : 10.1016/j.jenvman.2011.11.001

Stoate, C., Báldi, A., Beja, P., Boatman, N.D., Herzon, I., van Doorn, A.M., de Snoo, G.R., Rakosy, L., Ramwell, C., 2009. Ecological impacts of early 21 st century agricultural change in Europe - A review. Journal of Environmental Management 91 (1): 22 - 46.

Taky, A., Mailhol, J.C, Belaud, G., 2009. Using a furrow system for surface drainage under unsteady rain. Agricultural Water Management 96 (7): 1128-1136.

Toy, T.J., Foster, G.R., Renard, K.G., 2005. Soil Erosion: Processes, Prediction, Measurement and Control. John Wiley and Sons, New York, 338 pp.

USDA (Ed.), 2003. Keys to Soil Taxonomy, 9th edition, Natural Resources Conservation service, Keys to Soil Taxonomy, 9th edition. Natural Resources Conservation Service, $332 \mathrm{p}$.

Wilson, C. A. M. E., Stoesser, T., Bates, P. D., 2005. Modelling of open channel flow through vegetation (in: Computational Fluid Dynamics: Applications in Environmental Hydraulics). John Wiley and Sons.

Wondolleck, J., Yaffe, S., 2000. Making Collaboration Work: Lessons from Innovation in Natural Resource Management, Island Press, Washington, DC.

Wu, F. C., Shen, H. W., Chou, Y. J., 1999. Variation of roughness coefficients for unsubmerged and submerged vegetation. Journal of Hydraulic Engineering 9, 934-942. 
Author- produced version ot the article published in Journal of Environmental Management, 2011, 96,76-85.

The original publication is available at http://www.sciencedirect.com doi : 10.1016/j.jenvman.2011.11.001

Table 1: Decision table for evaluating infiltration rate and sediment concentrations in runoff from silty loam soils with low clay and organic matter contents, with soil surface roughness set at 1-2 cm, for a typical $25 \mathrm{~mm}$ spring rainfall event with a previous rainfall of $10 \mathrm{~mm}$ and a maximum rainfall intensity of $40 \mathrm{~mm} \cdot \mathrm{h}^{-1}$.

Table 2: Simulated runoff and sediment yields for each scenario at site A (A0, A1, A2; 41 ha) and at site $\mathrm{B}$ (B0, B1, B2, B3; 107 ha).

Table 3: Gross income, CAP subsidy, production costs (excluding cost of harvest), and average yield and price of winter (wheat and rape) and spring (maize and sunflower) crops in the Midi-Pyrénées region (Midi-Pyrénées Chamber of Agriculture, 2006). 
Table 1

Land use Vegetation Soil surface Infiltration Sediment

\begin{tabular}{lcccc} 
& cover & crusting & rate $\left(\mathrm{mm} \cdot \mathrm{h}^{-1}\right)$ & concentration $\left(\mathrm{g} . \mathrm{L}^{-1}\right)$ \\
\hline Spring crop & $<20 \%$ & $\begin{array}{c}\text { transitional } \\
\text { crust }\end{array}$ & 5 & 5 \\
\hline Winter crop & $>60 \%$ & $\begin{array}{c}\text { transitional } \\
\text { crust }\end{array}$ & 10 & 2 \\
\hline $\begin{array}{l}\text { Grassland or } \\
\text { set-aside }\end{array}$ & $>60 \%$ & $\begin{array}{c}\text { structural } \\
\text { crust }\end{array}$ & 20 & 5 \\
\hline Forest & $>60 \%$ & fragmentary & 50 & 0
\end{tabular}

(fragmentary stage: initial fragmentary structure with all fragments clearly distinguishable; structural crust: altered fragmentary state with local structural crust; transitional crust: generalized structural crust with local appearance of depositional crust)

Table 2

\begin{tabular}{ccc} 
Scenario & $\begin{array}{c}\text { Runoff volume } \\
\left(\mathrm{m}^{3}\right)\end{array}$ & $\begin{array}{c}\text { Sediment yield } \\
\text { (tons) }\end{array}$ \\
\hline A0 & 3116 & 335 \\
A1 & 1677 & 248 \\
A2 & 1761 & 206 \\
\hline B0 & 3249 & 241 \\
B1 & 1508 & 112 \\
B2 & 2524 & 131 \\
B3 & 232 & 9
\end{tabular}

Table 3

\begin{tabular}{lccccc} 
& $\begin{array}{c}\text { Yield } \\
\left(\text { tons.ha }^{-1}\right)\end{array}$ & $\begin{array}{c}\text { Price } \\
\left(€ . \text { ton }^{-1}\right)\end{array}$ & $\begin{array}{c}\text { Costs } \\
\left(€^{-1} \mathrm{~h}^{-1}\right)\end{array}$ & $\begin{array}{c}\text { CAP subsidy } \\
\left(€ . \mathrm{ha}^{-1}\right)\end{array}$ & $\begin{array}{c}\text { Gross income } \\
\left(€ . \mathrm{ha}^{-1}\right)\end{array}$ \\
\hline Irrigated maize & 10.57 & 109.18 & 619 & 490 & 1025 \\
Sunflower & 2.17 & 215.21 & 226 & 300 & 541 \\
\hline Rape & 2.99 & 187.29 & 352 & 300 & 508 \\
Wheat & 5.99 & 104.51 & 308 & 300 & 618
\end{tabular}


Figure 2: Landscape features and cropping pattern in 2009 on the hillside at site A (a) and site B catchment (b). The original land use corresponds to scenario 0 for each site (denoted A0 and B0).

Figure 3: Scenarios A1 (a; grass strips along ditches) and A2 (b; grass strips at mid-slope) with the actual cropping pattern of site A.

Figure 4: Scenarios B1 (a; grass strips or grassland along river and ditches and actual cropping pattern of site B), B2 (b; cropping pattern with reorganisation of spring and winter crops), and B3 (c; cropping pattern with winter crops only).

Figure 5: Map of simulated total runoff accumulation (in $\mathrm{m}^{3}$; a) and total sediment yield accumulation (in metric tons; b) for scenario A0 (each figured "gray" cells of 25 square metres carried more than $8 \mathrm{~m}^{3}$ water runoff and $40 \mathrm{~kg}$ soil sediment).

Figure 6: Map of simulated total runoff accumulation $\left(\mathrm{m}^{3} ; \mathrm{a}\right)$ and total sediment yield accumulation (in metric tons; b) for scenario B0 (each figured "gray" cells of 25 square metres carried more than $8 \mathrm{~m}^{3}$ water runoff and $40 \mathrm{~kg}$ soil sediment). 


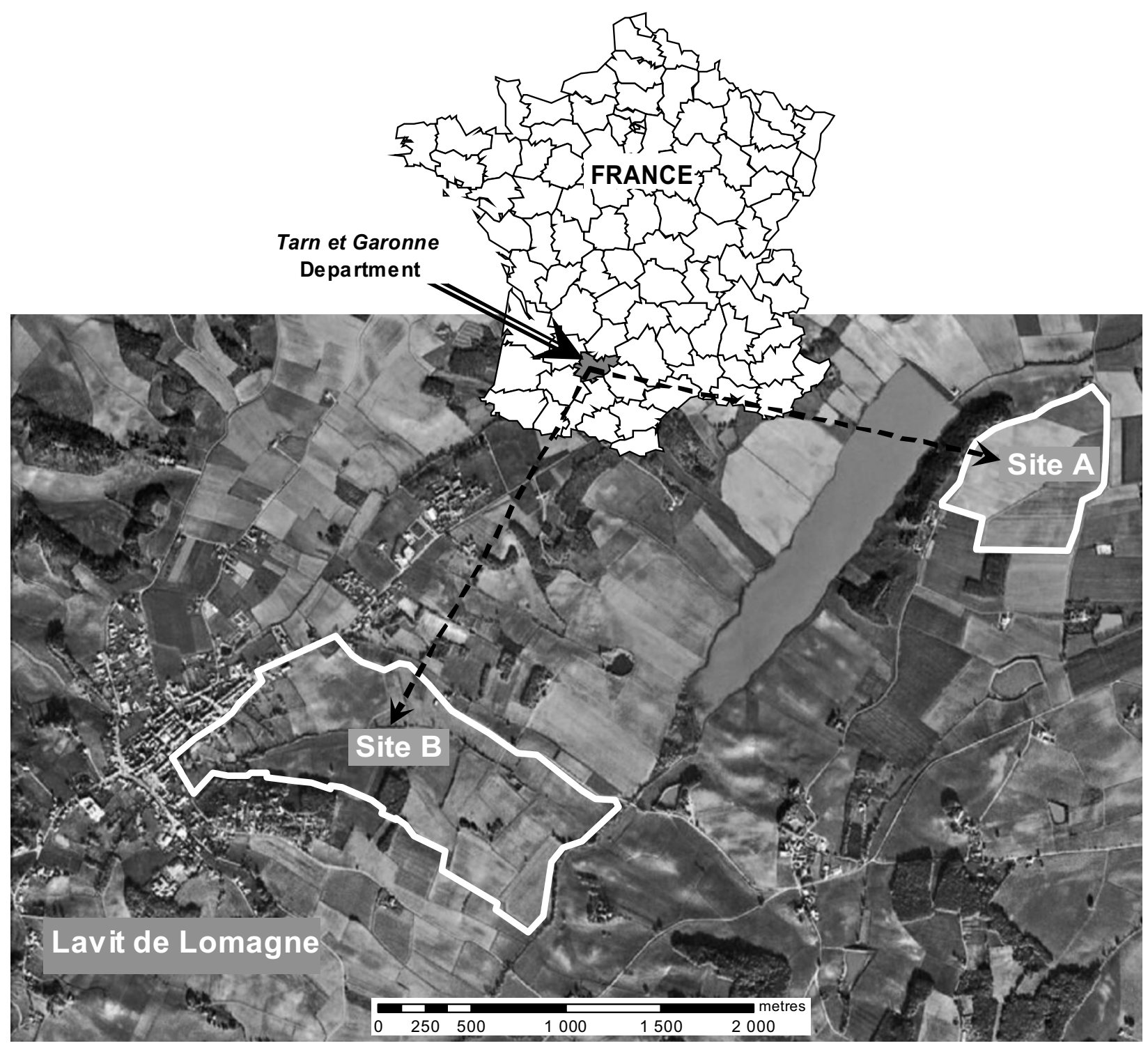


Author- produced version ot the article published in Journal of Environmental Management, 2011, 96,76-85. The original publication is availghate Bttp://www.sciencedirect.com doi : 10.1016/j.jenvman.2011.11.001

a) site $\mathrm{A}$

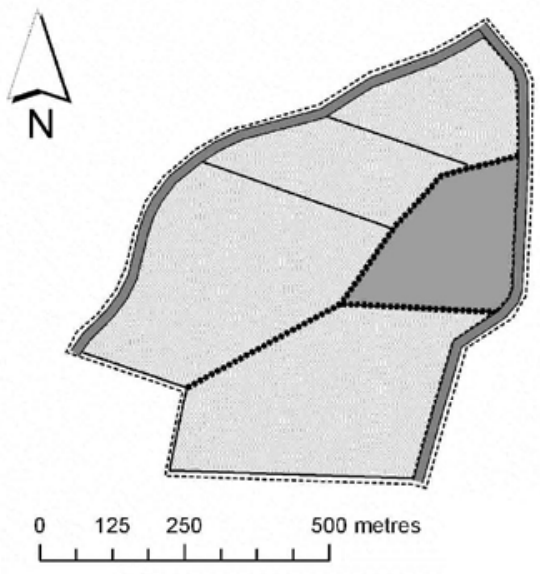

b) site $B$

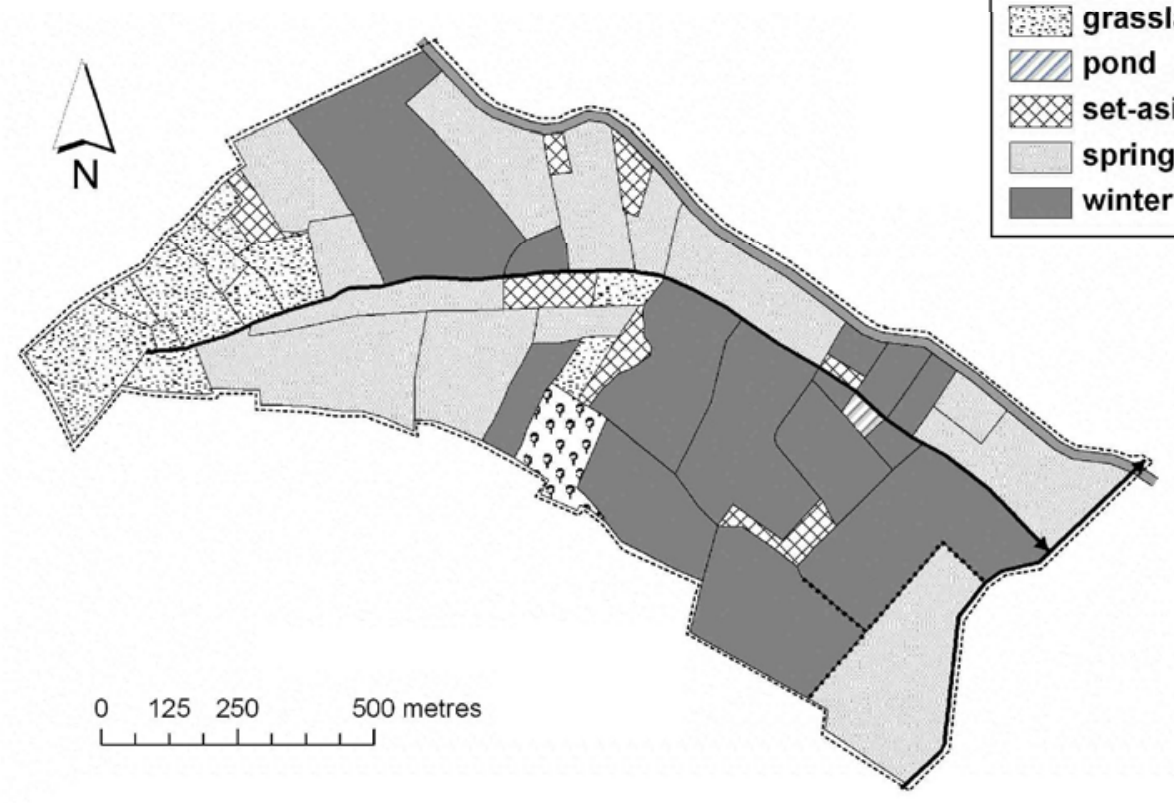


Author- produced version ot the article published in Journal of Environmental Management, 2011, 96,76-85.

The original publication is available at http://www.sciencedirect.com doi : 10.1016/j.jenvman.2011.11.001

Figure 3

a) A1

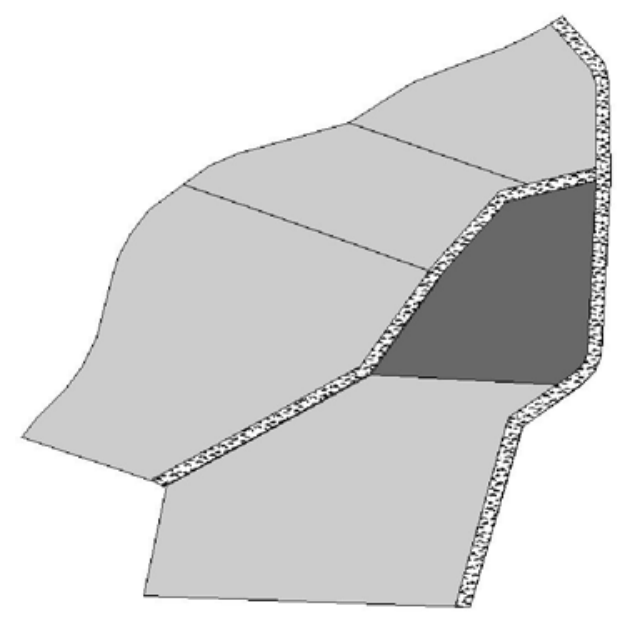

b) A2

Legend
Frass strip
$\square$ Spring crop
$\square$ Winter crop

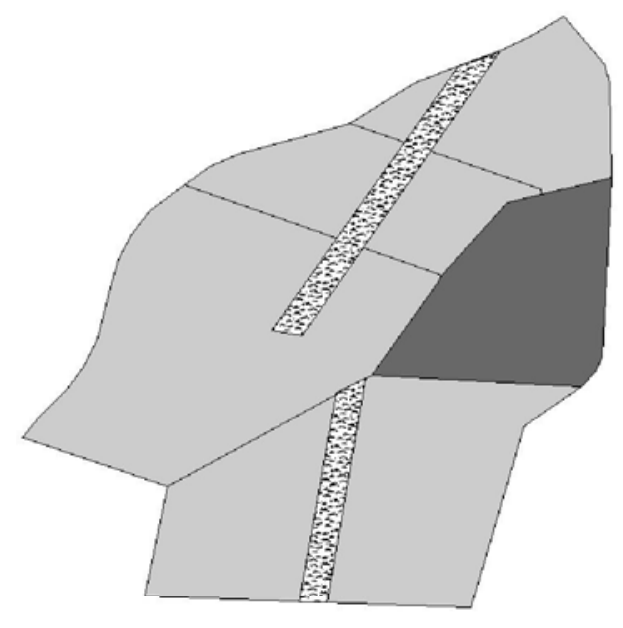


Author- produced version ot the article published in Journal of Environmental Management, 2011, 96,76-85.

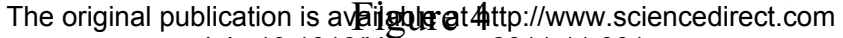
doi : 10.1016/j.jenvman.2011.11.001

a) B1

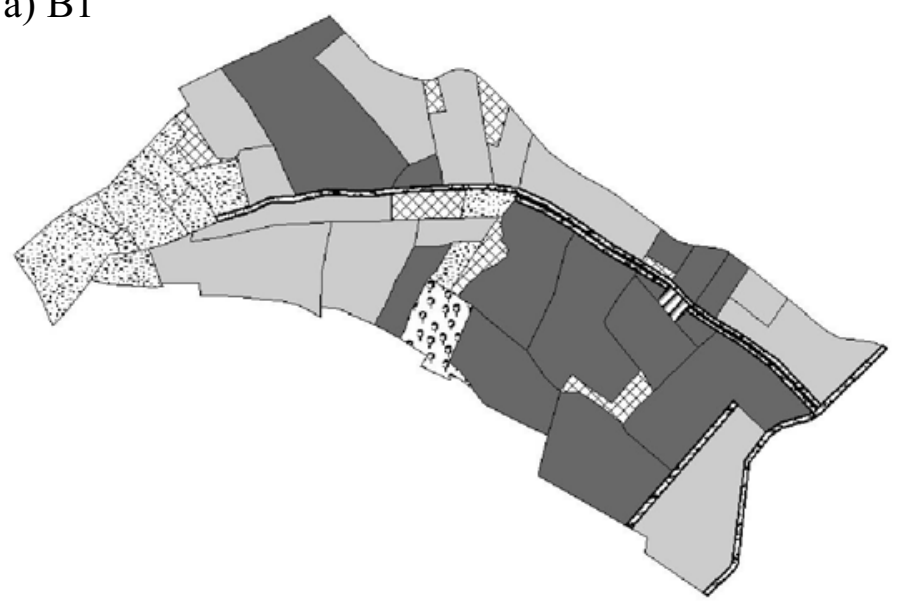

b) B2
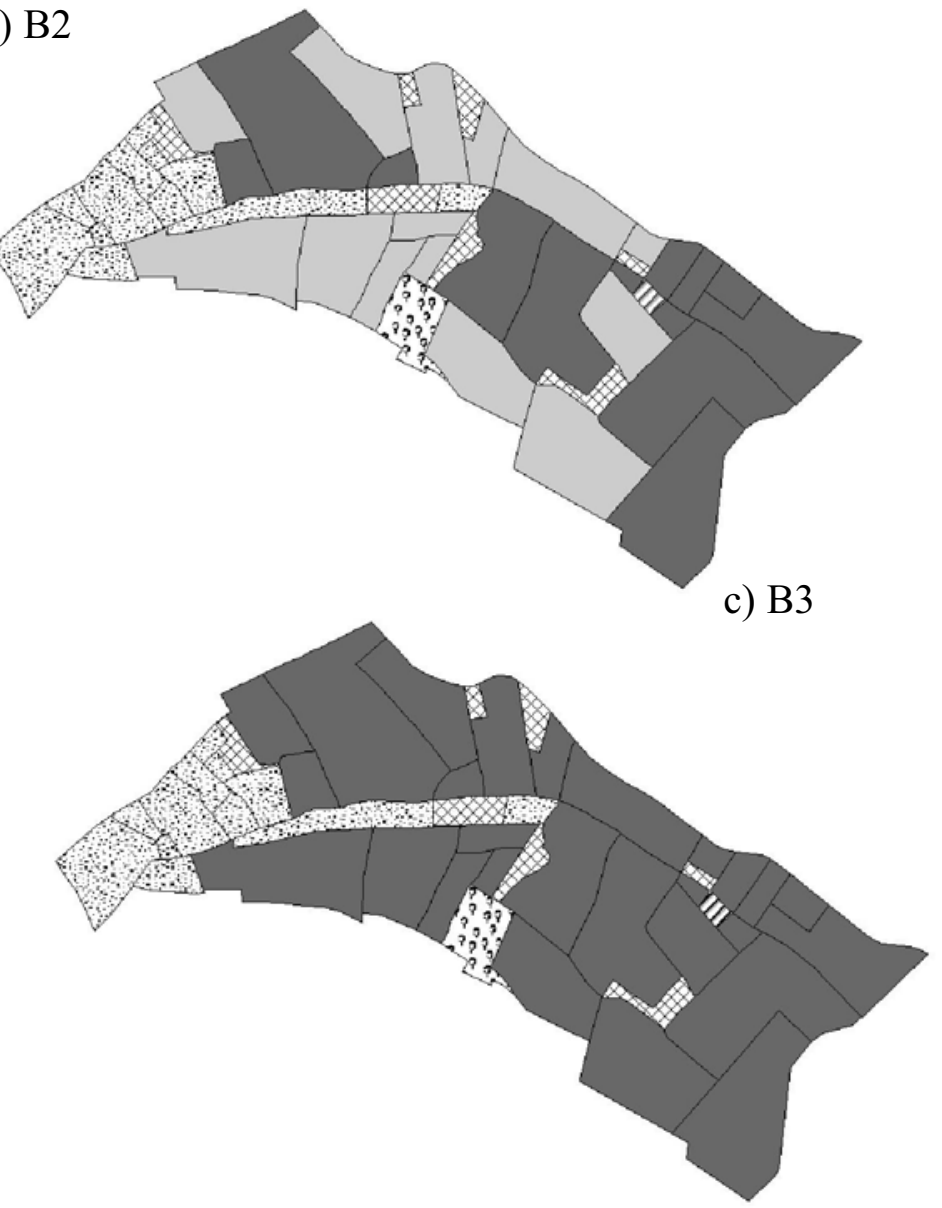
Author- produced version ot the article published in Journal of Environmental Management, 2011, 96,76-85.

The original publication is avaiighate 5 ttp://www.sciencedirect.com doi : 10.1016/j.jenvman.2011.11.001

a) runoff

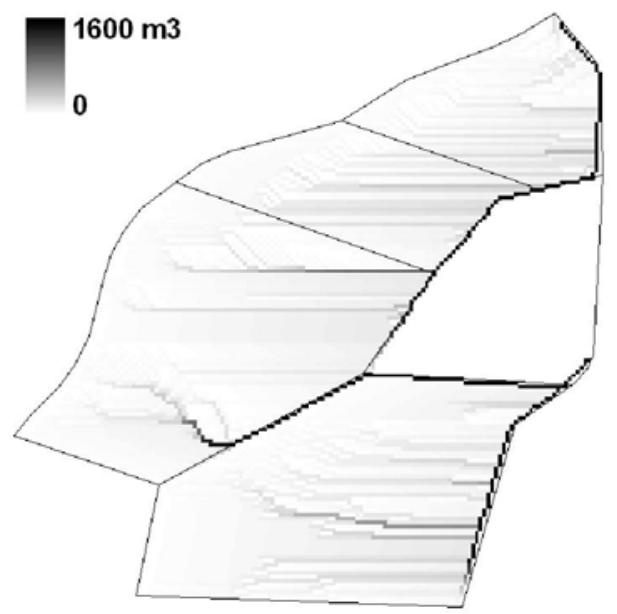

b) sediment yield

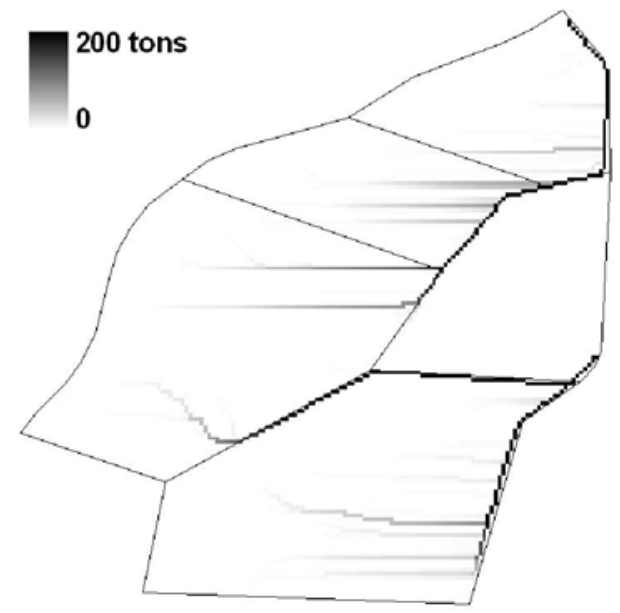


Author- produced version ot the article published in Journal of Environmental Management, 2011, 96,76-85.

The original publication is avaiighate (6ttp://www.sciencedirect.com doi : 10.1016/j.jenvman.2011.11.001

a)

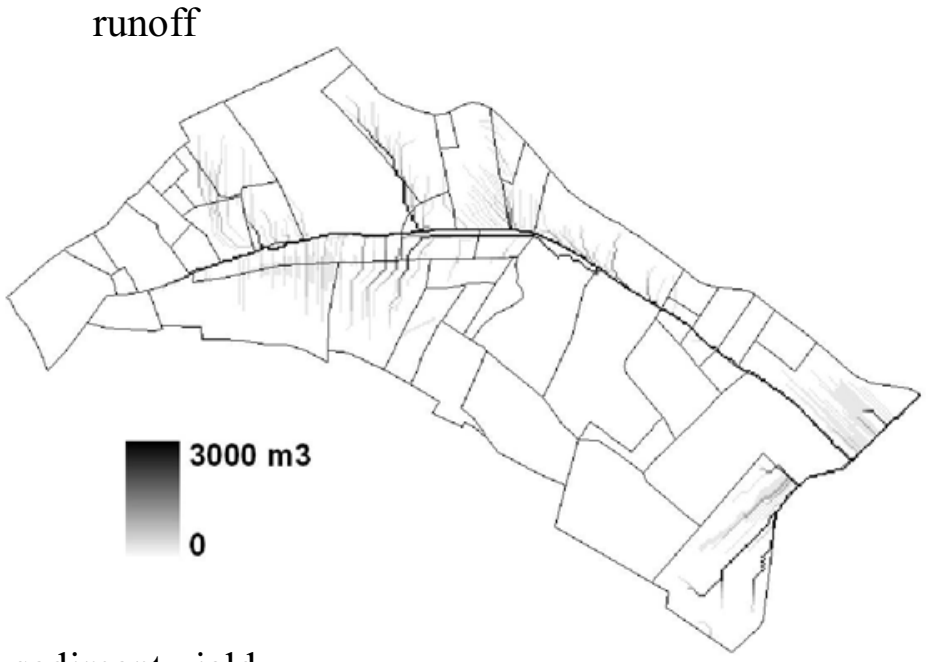

b) sediment yield

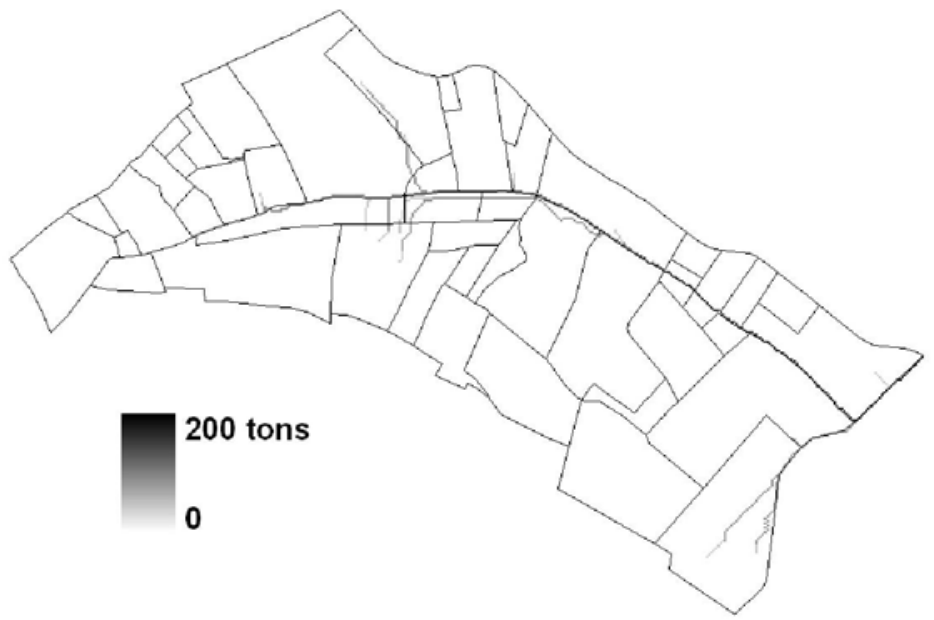

